\title{
THECALOSCOPY: A NOVEL METHOD IN SPINE SURGERY
}

\author{
TECALOSCOPIA: UM NOVO MÉTODO NA CIRURGIA DE COLUNA \\ TECALOSCOPIA: UN NUEVO MÉTODO EN LA CIRUGÍA DE LA COLUMNA VERTEBRAL
}

Alexey Kashcheev1, Sergey Arestov', Artem Gushcha ${ }^{1}$

1. Neurology Research Center, Department of Neurosurgery, Volokolamskoe Road, Moscow.

\begin{abstract}
Objetive: Thecaloscopy is a less invasive method of exploration of the spinal subarachnoid space, using an ultra-thin, flexible endoscope and endoscopic fenestration of scars and adhesions. Thecalopscopy was used in Russian neurosurgery for the first time. Methods: Since 2009, we have operated on 32 patients with the following diagnoses: 17 - spinal adhesive arachnoiditis (8 - local forms, 9 - diffuse forms), 12 - spinal arachnoid cysts ( 7 - post-traumatic cysts, 5 - idiopathic cysts), and 3 - extramedullary tumors (thecaloscopic videoassistance and biopsy). In all cases, we performed exploration of subarachnoid space and pathologic lesion with endoscopic perforation of the cyst or dissection of adhesions using special instrumentation. The mean follow-up time in our group was 11.4 months. Results: Neurological improvement (mean 1.4 by the modified Frankel scale, 1.8 by the Ashworth spasticity scale) was seen in $87 \%$ of patients operated for spinal arachnopathies. Temporary neurological deterioration (mild disturbances of deep sensitivity) was seen in $9 \%$ of patients and managed successfully with conservative treatment. One patient (3.1\%) was operated three times due to relapse of adhesions. There were no serious intraoperative complications (e.g. severe bleeding or dura perforation). Postoperative complications included one CSF leakage and one case of postoperative neuralgic pain. The mean hospitalization time was 7.6 days. Conclusion: According to our data, we conclude that thecaloscopy is efficient and safe method, and should be widely used for spinal arachnopathies, adhesive arachnoiditis and arachnoid cysts. Taking into account that adhesive spinal arachnoiditis is a systemic process, and that spinal arachnoid cysts may also be extended, thecaloscopy may be regarded as the most radical and less-invasive form of surgical treatment that currently exists in neurosurgery.
\end{abstract}

Keywords: Spinal cord; Arachnoiditis; Arachnoid cysts; Subarachnoid space; Endoscopy; Neuroendoscopy; Syringomyelia.

\section{RESUMO}

Objetivo: A tecaloscopia é um método menos invasivo de exploração do espaço subaracnóideo, com um endoscópio flexível ultrafino e fenestração endoscópica de cicatrizes e aderências. A tecaloscopia foi usada pela primeira vez na neurocirurgia russa. Métodos: Desde 2009, operamos 32 pacientes com os seguintes diagnósticos: 17 aracnoidites adesivas espinais (8 formas locais e 9 formas difusas), 12 cistos aracnóideos espinais (7 cistos pós-traumáticos e 5 cistos idiopáticos) e 3 tumores extramedulares (vídeo-assistida por tecaloscopia e biópsia). Em todos os casos, realizamos a exploração do espaço subaracnóideo e da lesão com perfuração endoscópica do cisto ou dissecção de aderências usando instrumentação especial. O acompanhamento médio em nosso grupo foi de 11,4 meses. Resultados: A melhora neurológica (média 1,4 pela escala de Frankel modificada e 1,8 pela escala de espasticidade de Ashworth) foi observada em 87\% dos pacientes operados devido a aracnopatias da coluna vertebral. A deterioração neurológica temporária (distúrbios leves da sensibilidade profunda) foi observada em 9\% dos pacientes que foi tratada com sucesso pelo método conservador. Um paciente (3,1\%) foi operado três vezes devido à recorrência de aderências. Não houve complicações intraoperatórias graves (por exemplo, sangramento grave ou perfuração da dura-máter, etc.). As complicações pós-operatórias incluíram um extravasamento de LCE e um caso de neuralgia pós-operatória. O período médio de hospitalização foi de 7,6 dias. Conclusão: De acordo com nossos dados, concluímos que a tecaloscopia é um método eficiente e seguro, e deve ser amplamente utilizado para aracnopatias espinais, aracnoidites adesivas e cistos aracnóideos. Considerando que a aracnoidite adesiva é um processo sistêmico e que os cistos aracnóideos da coluna vertebral também podem ser extensos, a tecaloscopia pode ser considerada como a forma mais radical e menos invasiva de tratamento cirúrgico existente atualmente em neurocirurgia.

Descritores: Medula espinal; Aracnoidite; Cistos aracnóideos; Espaço subaracnóideo; Endoscopia; Neuroendoscopia; Siringomielia.

\section{RESUMEN}

Objetivo: La tecaloscopia es un método de exploración menos invasivo del espacio subaracnoideo con un endoscopio flexible ultrafino y fenestración endoscópica de cicatrices y adherencias. La tecaloscopia se utilizó en neurocirugía rusa por primera vez. Métodos: Desde 2009 operamos 32 pacientes con los siguientes diagnósticos: 17 aracnoiditis adhesivas espinales (8 formas locales y 9 formas difusas), 12 quistes aracnoideos espinales (7 quistes postraumáticos y 5 quistes idiopáticos) y 3 tumores extramedulares (asistida por video tecaloscópico y biopsia). En todos los casos se realizó la exploración del espacio subaracnoideo y lesión con perforación endoscópica del quiste o disección de adherencias mediante instrumentación especial. El seguimiento medio en nuestro grupo fue de 11,4 meses. Resultados: La mejoría neurológica (media 1,4 por la escala de Frankel modificada y 1,8 por la escala de espasticidad de Ashworth) se observó en el $87 \%$ de los pacientes operados debido a aracnopatías de la columna vertebral. Se observó deterioro neurológico temporal (alteraciones leves de la sensibilidad profunda) en el $9 \%$ de los pacientes, que fue tratada con éxito por el método conservador. Un paciente (3,1\%) fue operado tres veces debido a la recurrencia de las adherencias. No hubo complicaciones intraoperatorias graves (por ejemplo, sangrado grave o perforación de la duramadre, etc.). Las complicaciones postoperatorias incluyeron una extravasación del LCR y un caso de neuralgia 
postoperatoria. El período promedio de hospitalización fue de 7,6 días. Conclusiones: De acuerdo con nuestros datos, concluimos que la tecaloscopia es un método eficiente y seguro, que debe ser ampliamente utilizado para aracnopatías espinales, aracnoiditis adhesivas y quistes aracnoideos. Teniendo en cuenta que la aracnoiditis adhesiva es un proceso sistémico y que los quistes aracnoideos de la columna vertebral también pueden ser extensos, la tecaloscopia puede ser considerada como la forma más radical y menos invasiva de tratamiento quirúrgico existente actualmente en neurocirugía.

Descriptores: Médula espinal; Aracnoiditis; Quistes aracnoideos; Espacio subaracnoideo; Endoscopía; Neuroendoscopía; Siringomielia.

\section{INTRODUCTION}

Thecaloscopy is a minimally invasive surgical procedure performed for therapeutic and/or diagnostic purposes, in which a flexible endoscope is inserted into the dural sac.

In 2001, Warnke et al. (Paracelsus-Klinik Zwickau, Germany) coined a new term, thecaloscopy, to describe endoscopy of the subdural space using a flexible optical fiber. ${ }^{1}$ This choice of the word was based on the fact that the authors considered punctuate intrathecal delivery of narcotic agents in patients with intractable cancer pain syndrome to be the primary goal of the method.

Thecaloscopy is a modern method of spinal cord endoscopic surgery that so far, has seen limited use worldwide. It is rarely described in the literature, and the reports that do exist are mostly of clinical cases. Likewise, no articles were found demonstrating the application of this technology in Russia. However, all related international articles note that the prospects of thecaloscopy application are very broad, especially for the surgical treatment of spinal arachnoiditis and spinal arachnoid cysts. ${ }^{2}$ These factors indicate the relevance of research on thecaloscopy.

\section{METHODS}

\section{Indications}

As mentioned above, thecaloscopy can be performed independently, or used during microsurgical interventions for video assistance. Indications for thecaloscopy include:

- True or false spinal arachnoid cysts of various sizes and origins (including post-traumatic cysts);

- Adhesive spinal arachnoiditis causing long tract or radicular signs that reduce the patient's quality of life and that have failed to respond to rehabilitation treatment or conservative therapy;

- Syringomyelia associated with processes of adhesion in the subarachnoid space of spinal cord;

- Extramedullary masses (biopsy and video assistance during extraction);

- Spinal cord fixation syndrome.

\section{Contraindications}

- Severe somatic diseases that carry a high surgical anesthetic risk;

- Active cerebrospinal or spinal inflammatory process (acute exudative arachnoiditis, purulent epiduritis, spondylodiscitis, etc.) confirmed by clinical laboratory test results;

- Marked immunodeficient diseases including HIV infection;

- Mental disorders and conditions that interfere with the understanding of the treatment plan;

- Marked and stable positive effect of conservative or rehabilitation treatment.

\section{Clinical picture of spinal adhesive arachnoiditis and arachnoid cysts}

Gusev et al. define 4 clinical forms of spinal arachnoiditis: 1) radicular sensitive; 2) motor cerebrospinal; 3) radicular cerebrospinal, or mixed; 4) radicular posterior-column. ${ }^{3}$

Spinal arachnoiditis may be acute, subacute, or chronic. Acute spinal arachnoiditis is the most typical form in patients with severe systemic infections, e.g. sepsis or bacterial meningitis. As it progresses, it may be accompanied by hyperthermia, fever, and events of acute phase response, or complicated by hemorheologic disorders, multiple organ failure, etc. in more complex cases. Neurological symptoms develop quickly, sometimes within several days and even hours, in the form of acute transverse myelitis with marked long tract signs Subacute spinal arachnoiditis also occurs in the setting of infections, but it progresses more latently within months, against the background of normal or subfebrile temperatures. Clear radicular signs are more commonly presented, with long tract signs being added later in the neurological status. In chronic spinal arachnoiditis, it is often not possible to identify the infectious agent, and the disease progresses very slowly; cumulative events of spastic and afferent paresis and pelvic diseases may appear. ${ }^{4}$

It should be noted that spinal arachnoid cysts may clinically resemble an extramedullary tumor, and this would sometimes lead to diagnostic errors until neurovisualization became more commonly used. Arachnoid cyst manifests as slowly progressing conduction disorders, CSF circulation disorders, or more infrequently, radicular signs, generally corresponding to the location of one of the adhesions on the cyst wall. Nowadays, a significant number of studies discuss experimental methods of modelling arachnoid cysts, and their significance for the development of syringomyelia. ${ }^{5}$

\section{Preoperative assessment plan}

As noted above, the clinical symptoms of cystic adhesive spinal arachnoiditis may vary to a great extent, while the patient's condition may range from subclinical complaints to marked disability. In some cases, especially after bacterial meningitis, the clinical symptoms of intracranial pathology may overlap with spinal symptoms. A significant number of arachnoid cysts, especially those of idiopathic form, may also be completely asymptomatic, but found incidentally in MRI

Therefore, the primary goal of preoperative assessment is to determine whether the patient's neurological symptoms are caused by spinal arachnoiditis or arachnoid cyst, and to rule out intercurrent pathologies. The exact algorithm of examination may differ depending on considerations related to the patient; however, a mandatory plan of preoperative assessment includes the following:

- Neurological examination (by a neurosurgeon and a neurologist);

- MRI of all relevant sections of the spine and spinal cord (magnetic field greater than 1.5-Tesla) with MR-myelography and, if necessary, CSF flow assay;

- Routine laboratory tests (including CRP) and tests for highly contagious diseases.

If necessary, the following can be also applied:

- Neurophysiological methods (electroneuromyography, somatosensory-evoked potentials, transcranial magnetic stimulation);

- Lumbar puncture (CSF pressure estimation; clinical, biochemical and microbiological CSF tests);

- MRI of the adjacent sections of spinal cord;

- CT of the spine;

- Consultations with neurologists, neurodegenerative and experts in demyelinating disease.

The study was approved by the local Ethics Committee (Protocol Approval No. 12/12, 10.10.2012).

\section{Description of technology \\ Equipment}

In our investigation, we use a flexible endoscope (fiberscope) manufactured by Karl Stors (Germany) (Figure 1). The lengths of the two endoscope sets were $40 \mathrm{~cm}$ and $70 \mathrm{~cm}$. The latter length enables full-scale exploration of all the subarachnoid space, from the cauda equina roots up to the craniovertebral transition in an adult patient. Fiberscope is compatible with a standard endoscopic rack. 
The base of the fiberscope is equipped with a manipulator which allows it to bend distally up to 270 degrees in either direction (Figure 2). This function allows full-scale visualization and exploration of the ventral and dorsal subarachnoid spaces.

The diameter of a working surface is $2.8 \mathrm{~mm}$; it is equipped with a light source, video camera for image transmission, and one working channel of 1.2-mm diameter (Figures 3, 4). This channel can be used for irrigation during surgical intervention or visuallycontrolled introduction of manipulators, allowing for adhesiotomy and biopsy sampling.

Recently, digital flexible endoscopes ("chip-on-tip" technology) have been developed whose optical resolution exceeds that of standard fiberscopes with identical working surface diameter. Preliminary results of clinical application of digital endoscopes show that they can be effectively used not only for spinal cord surgery, but also for brain endoscopy, such as third ventriculostomy, biopsy of tumors in the ventricular system, endoscopic drainage, and fibrinolysis of hypertensive intracerebral hemorrhages. This digital endoscopic technology provides very high quality visualization of the intracranial structures (Figure 5).

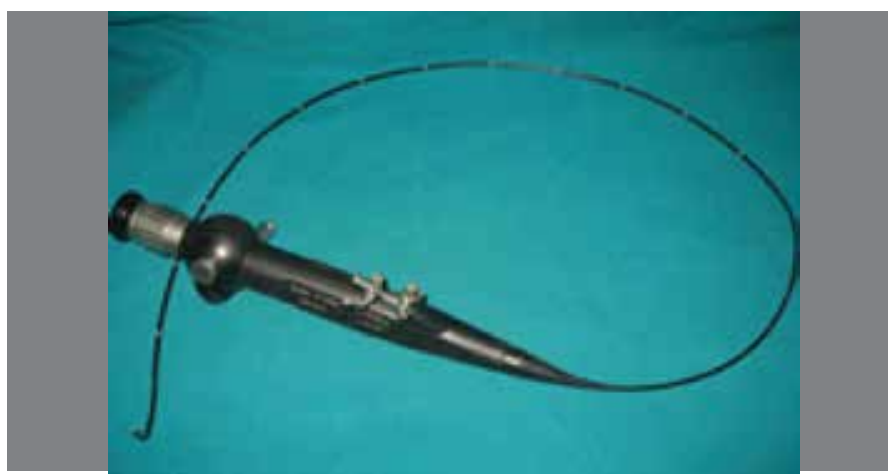

Figure 1. Full view of the thecaloscope.

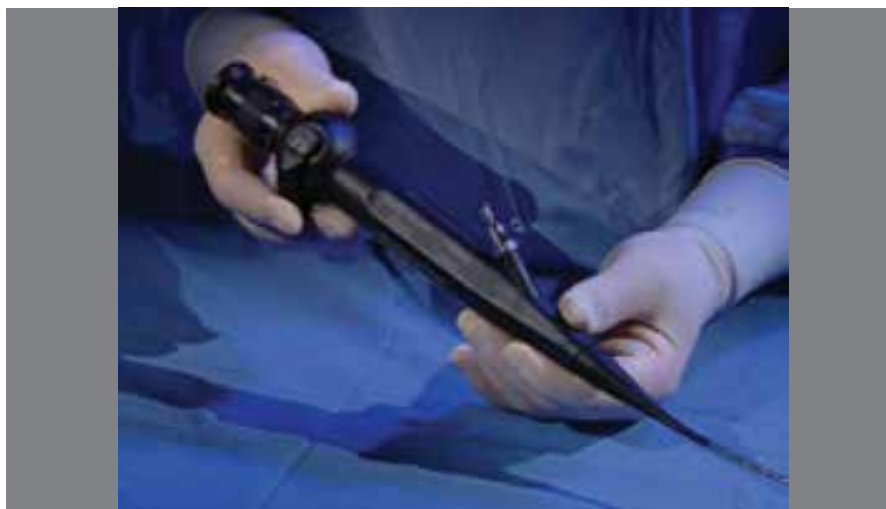

Figure 2. Control of the distal part of the thecaloscope using a manipulator.

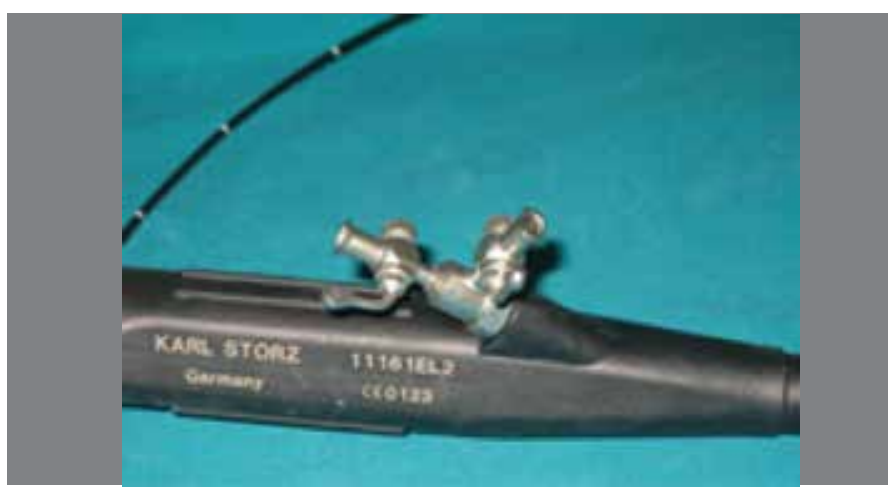

Figure 3. Manipulation channels of the thecaloscope (diameter $1.2 \mathrm{~mm}$ ).

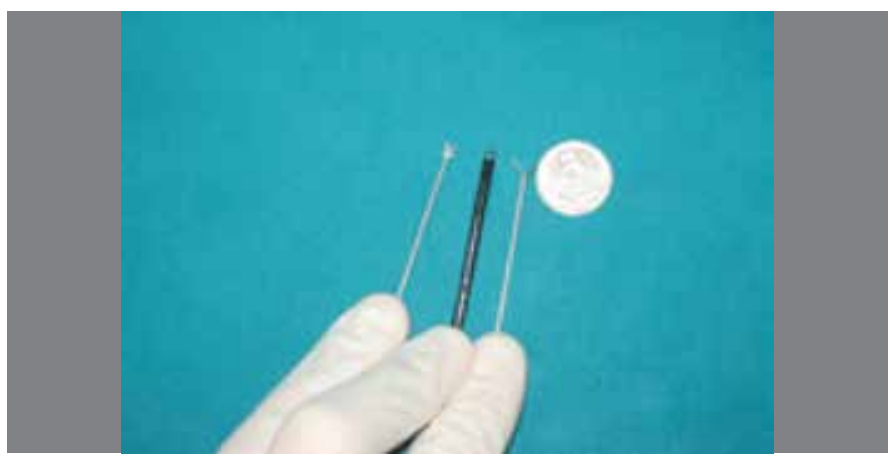

Figure 4. Size comparison of the manipulators and the distal part of thecaloscope (working surface diameter $2.8 \mathrm{~mm}$ ).

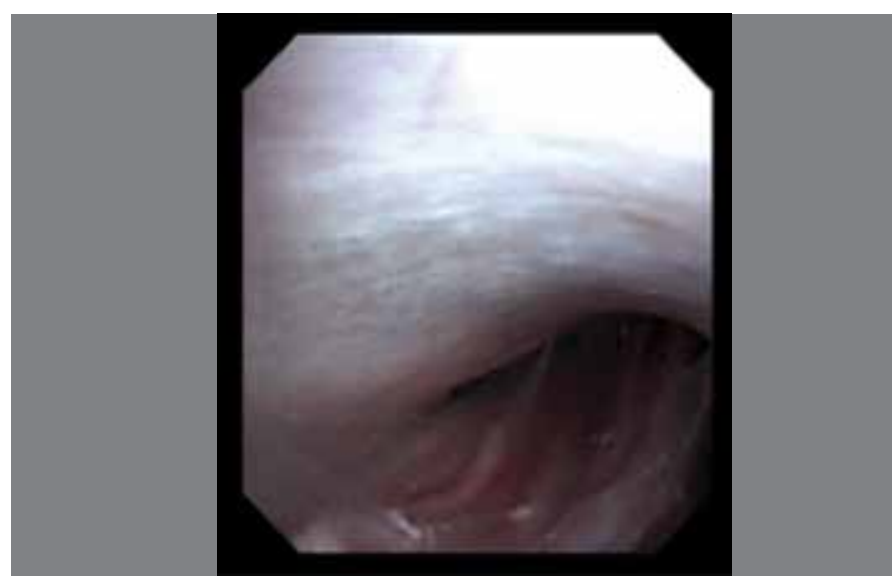

Figure 5. Digital "chip-on-tip" endoscopy: nerve roots and dura mater.

\section{Surgical technique}

The intervention is performed in the supine position. Like thecaloscopy is a minimally invasive intervention, it can be performed under either endotracheal anesthesia or local infiltration anesthesia via puncture. In the case of surgery to the upper cervical spine, the patient's head is securely fixed with a Mayfield fixture. An endoscopic rack is placed opposite the operating surgeon. Intraoperative fluoroscopy is used.

According to the principles of minimally invasive surgery, the surgical approach should be as minimally invasive as possible, but should fully correspond to the intervention goals. Therefore, there are various techniques of surgical approach.

In limited spinal cysts or single adhesions (Figure 6), the approach is performed directly above the compression site, enabling microsurgical dissection of the adhesions (Figure 7).

In extended arachnoid cysts, the approach is performed in the central section of the cyst (Figure 8). This allows the endoscope to be conveniently manipulated in both the cranial and caudal directions.

If a patient has marked adhesions, extended adhesive arachnoiditis and a variety of symptoms related to the impairment of various sections of the spinal cord and its roots (Figure 9), or if the adhesions are located in a dangerous area (e.g. conus or epiconus), it is safer to perform the surgical approach in a caudal direction from the conus. This allows a greater cross dimension of subarachnoid space to be used, and lowers the risk of worsening of neurological symptoms.

When using the open surgical approach, according to the selected technique, a skin and soft tissue incision is performed in the projection of the target spinal segment, under the control of intraoperative radiography. The spinous processes and vertebral arches are skeletonized at the target level. Further laminectomy is performed; it is typically limited to one vertebral arch (which corresponds to a skin incision $5-7 \mathrm{~cm}$ long). The length of the spinal dura mater incision does not exceed $2 \mathrm{~cm}$. Effective hemostasis is of fundamental importance (including hemostasis using modern hemostatic materials), as even minimal bleeding can complicate the endoscopic visualization. 


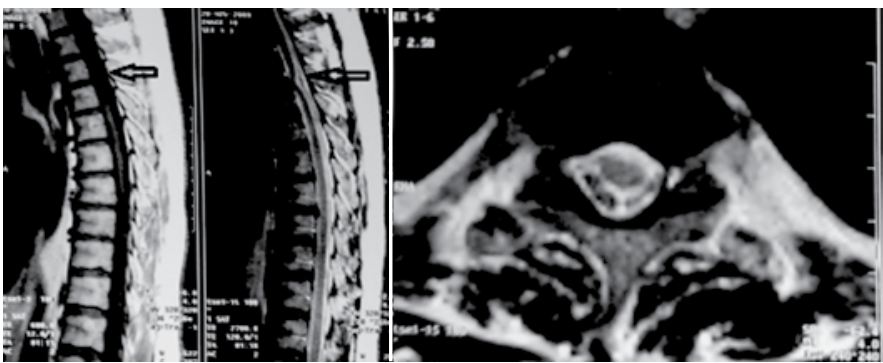

Figure 6. Limited spinal adhesive arachnoiditis at the Th3 level.

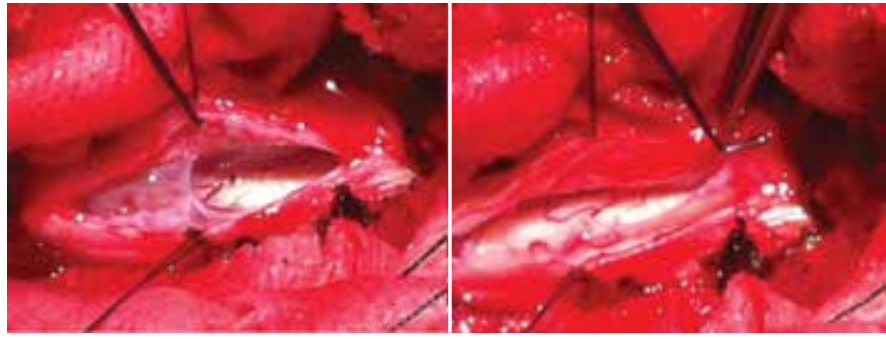

Figure 7. Microsurgical adhesiolysis before the thecaloscopy stage during surgery.

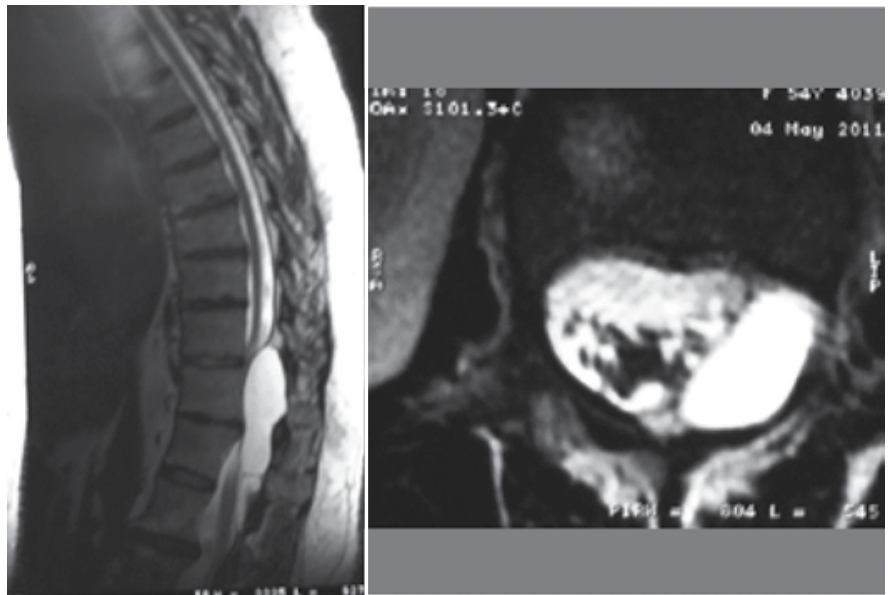

Figure 8. Extended arachnoidal post-traumatic cyst at Th9-Th11 level.

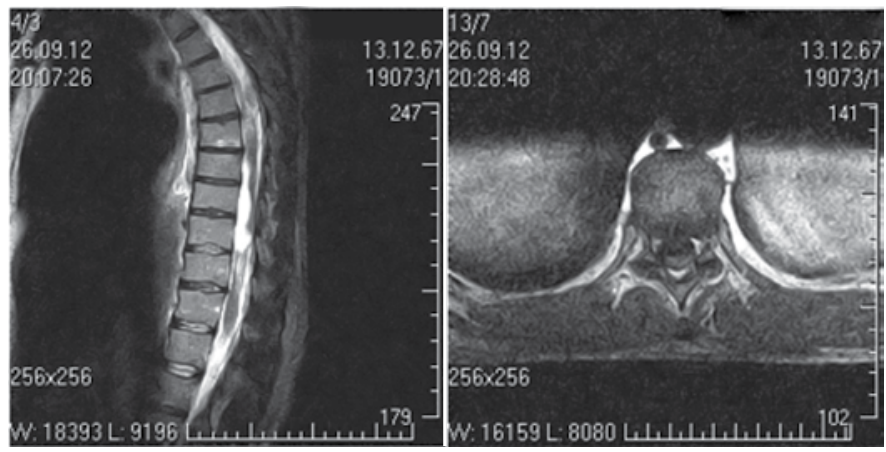

Figure 9. Extended postinfectious arachnoiditis of the middle thoracic spine.

The main stage, thecaloscopy, is performed after microsurgical dissection of visible adhesions and cyst walls. The fiberscope is introduced into the dorsal subarachnoid space and, if needed, into the ventral space, by bending the distal end using the manipulator (Figure 10). If necessary, the endoscope positioning is controlled by an electro-optical converter.

This method enables clear visualization of the adhesions and cyst walls (Figure 11) and various anatomic (Figure 12) and pathological masses (Figure 13).

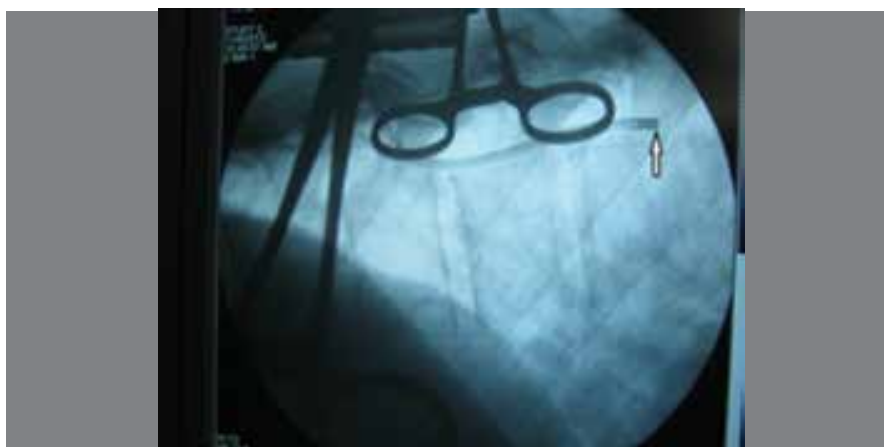

Figure 10. Thecaloscopy of the ventral subarachnoid space. The distal end of the thecaloscope is marked with an arrow.

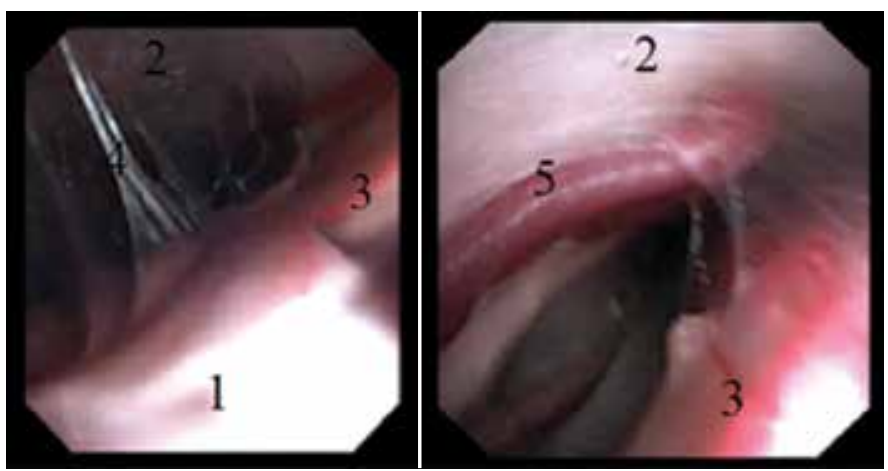

Figure 11. Videoendoscopy of the dorsal subarachnoid space (Th10-Th11) 1 - arachnoid membrane; 2 - dura; 3 - nerve root; 4 - arachnoid scar; 5 - radicular artery.

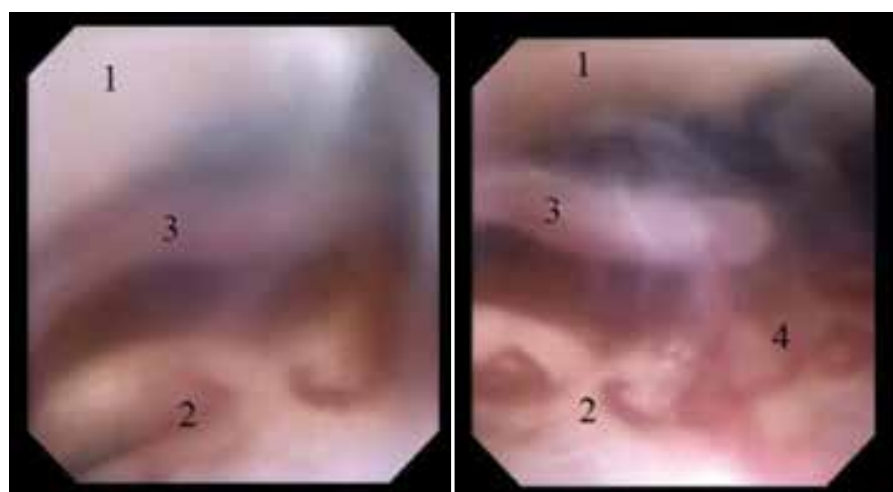

Figure 12. Videoendoscopy of the dorsal subarachnoid space (C0-C1). 1- Dura at the craniovertebral level; 2 - brainstem; 3-vertebral artery, V4; 4- pial vessels.

Adhesiotomy and cyst fenestration can be performed both by endoscope itself and by manipulators (Figure 14). In thecaloscopy, all the manipulations should be smooth, without forcing, in order to prevent marked spinal traction and exacerbation of neurological symptoms. It should be noted that technical features of this method require of a surgeon a certain experience in image interpretation. In particular, it is necessary to become accustomed to the meshed form that is typical for all ultrafine flexible endoscopes, the higher picture quality in reverse motion of fiberscope, and the continuous need for correct orientation in the 2D space.

Bleeding caused by arachnoid blood vessels, often pathologically changed, can be halted by continuous irrigation with saline solution. We have not observed any excessive or continuous bleeding in our practice. Also, a semiconductor diode laser can be used for coagulation.

Significant attention is paid to the prevention of CSF leakage, which is relatively likely in patients with arachnoiditis due to the structural changes in spinal dura mater. In some cases, application of a watertight closure of spinal dura mater is not sufficient, and spinal dura mater surgery is needed, including collagen transplants. 


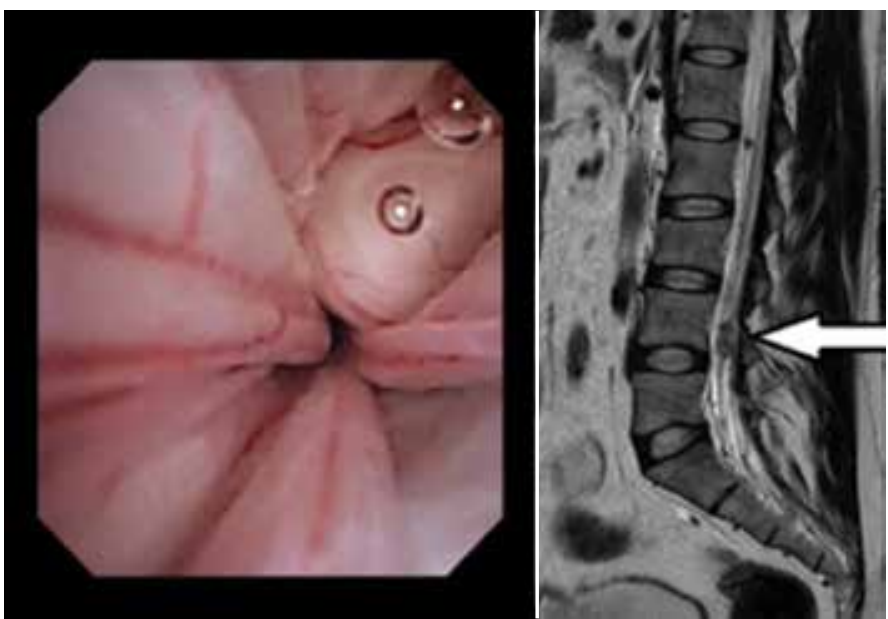

Figure 13. Thecaloscopy: neurofibroma at L4 level.

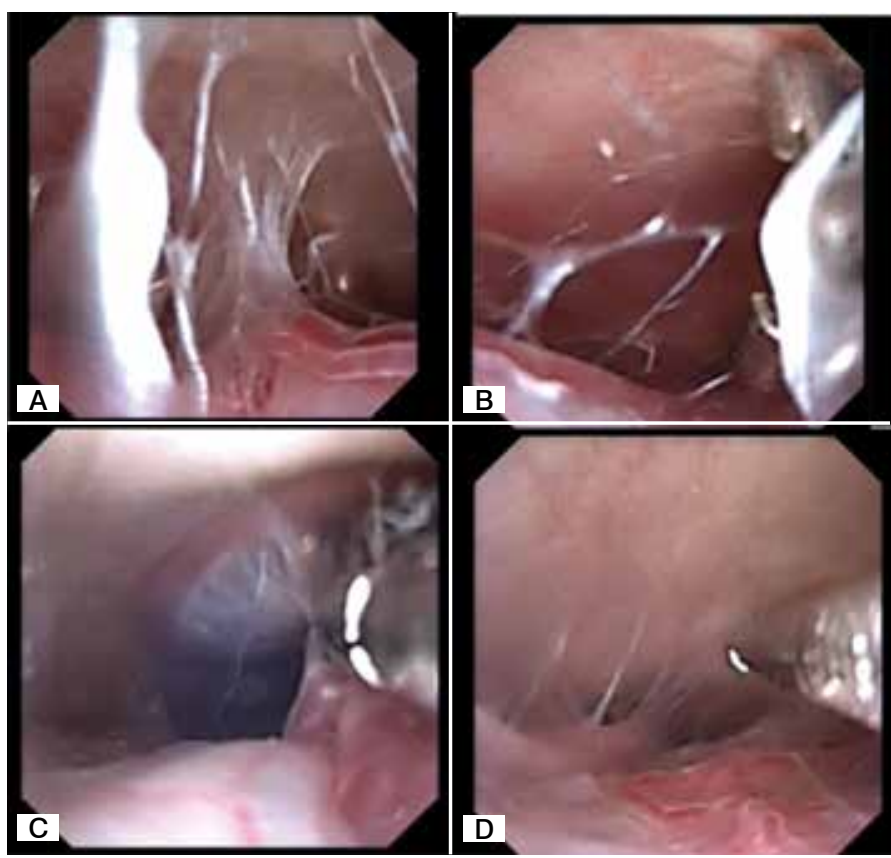

Figure 14. Extraction of arachnoid adhesions during thecaloscopy. a Arachnoid scars; b, c-Cyst fenestration by the manipulator; $d$ - endoscopic decompression.

\section{Postoperative management}

Generally, the patient is encouraged to walk as soon as possible, preferably the day following surgery. Early start of rehabilitation, under control of neurorehabilitation experts, is of great importance. The patient receives antibiotic preventative care, glucocorticosteroids, and symptomatic treatment. On the day following the intervention, lumbar puncture is performed with CSF pressure estimation and irrigation with dioxidine, which promotes sanitation of the subarachnoid space. The average hospitalization time for microsurgery is 7-10 days. It should be noted that puncture thecaloscopy can be performed in the inpatient setting in one day.

\section{Assessment of surgery results}

It is reasonable to estimate the results at the day of patient's activation, at discharge and in 6 months after the surgery, then annually. The following measures are usually used:

- Neurological examination over time;

- Modified Frankel scale;

- Results of neurovisualization (MRI, including in MR-myelography);

- Registration of complications.

\section{Complications and unsatisfactory outcomes}

According to our results, complications from thecaloscopy are rare, and are no more common than complications from other forms of spinal neurosurgery. No serious intraoperative complications have been reported to date. Besides general surgical and anesthetic complications, liquorrhea or cerebrospinal cyst of the soft tissues, or reactive aseptic meningitis may develop.

A possible unsatisfactory result of the surgery is relapse of the adhesion, which may develop after the surgery and can result in worsening of neurological symptoms (3.1\% of patients in our group). According to our data, these cases are rare; prevalence of cystic adhesive arachnoiditis, system inflammatory processes, immunoreactive disorders, tendency to adhesive processes and formation of adhesions appear to be predictors of such outcome ${ }^{6}$ (Figure 15). The patient should be warned about the possibility of such outcomes.

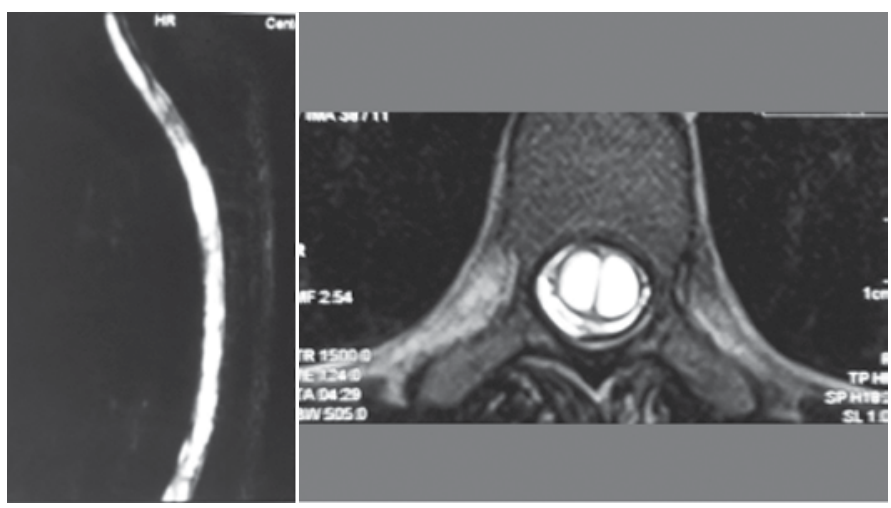

Figure 15. Marked postinfectious adhesive arachnoiditis with syringomyelia.

\section{RESULTS}

We used this method for the first time in November 2009. 27 surgeries were performed during last 3 years, 32 patients have been operated on, 17 with surgery for adhesive spinal arachnoiditis (8 for limited form, 9 for diffuse form), 12 for spinal arachnoid cysts (7 for posttraumatic, 5 for idiopathic ones), and 3 for extramedullary tumor (thecaloscopic video assistance and biopsy were performed). In all cases, visualization of all relevant subarachnoid spaces was implemented in the ventral and dorsal regions. Surgical treatment for cystic and adhesive processes included thecaloscopic adhesiotomy, fenestration of the cyst walls and subarachnoid space, and exploration in the caudal and cranial directions from the surgical approach. The results were estimated using the Modified Frankel scale, Ashworth scale, and MRI images.

The average follow-up time was 11.4 months. Regression of neurological symptoms was observed in the follow-up visits in $87 \%$ patients operated for cystic adhesions; the average improvement scored 1.4 on the Modified Frankel Scale and 1.8 on the Ashworth Scale. (Figure 16)

Transient disturbances of deep sensitivity were seen in $9 \%$ of patients and managed successfully with conservative treatment. Repeated MRI revealed relapse of adhesions in one patient (3.1\%) with severe extended adhesive arachnoiditis; due to relapses, this patient was operated on three times, at intervals of six and eight months. After each thecaloscopy, a positive clinical outcome was observed; however, neurological symptoms progressed to the initial level within the abovementioned period. There were no serious intraoperative complications reported (bleeding, spinal dura mater perforation). Postoperative complications included one CSF leakage and one transient intercostal neuralgia (Figure 17). The average hospitalization time was 7.6 days.

\section{Clinical case}

Patient S., 29 years old. Disability group I. On admission to the Department of Neurosurgery of the Neurology Research Center of the Russian Academy of Medical Sciences, the patient complains about 


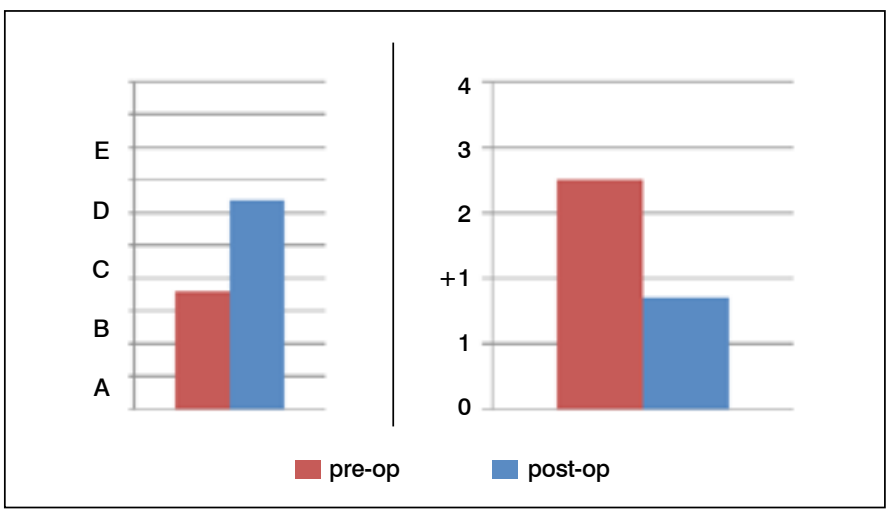

Figure 16. Results of the follow-up examination (average follow-up 11.4 months): a - Modified Frankel Scale (average improvement of motor function scored 1.4) $;$; b-Ashworth Scale (average decrease of limb spasticity scored 1.8)*; pre-op and post-op data are marked in red and blue, respectively.

* Modified Frankel Scale: A (complete injury) - no motor or sensory function clinically detected below the level of the injury; B (preserved sensation only) - sensory function partially preserved below the level of the injury; no voluntary movements. C - (minimum motor function) - motor functions are preserved with significant strength reduction down to 2; D (preserved motor function) - motor functions preserved below the level of injury with the strength of more than 3; patient can walk with or without aid; $E$ (normal motor) - normal motor or senn mote - in muscle range of motion when the affected part is moved in flexion or extension. $1+$ - slight increase in muscle tone, manifested by a catch, followed by minimal resistance throughout the less than half of the range of movement; 2 - more marked increase in muscle tone through most of the range of movement, but affected part easily moved; 3 - considerable increase in muscle tone passive, movement difficult; 4 affected part rigid in flexion or extension (flexion or extension contracture).

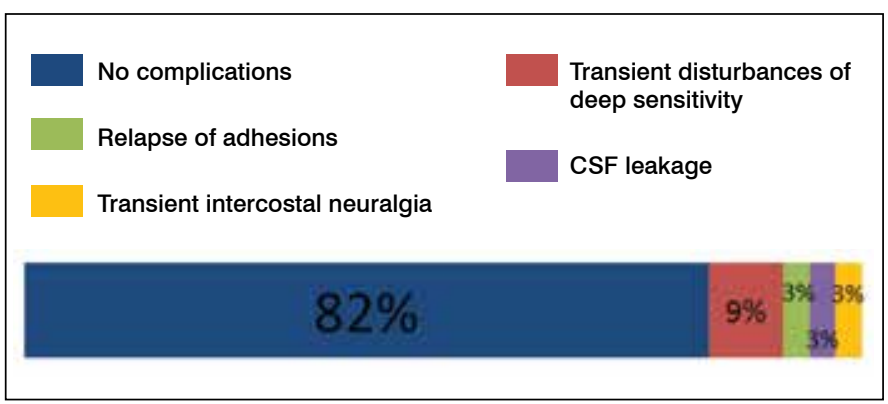

Figure 17. Complications of thecaloscopy.

difficulty walking, spastic sensations in the legs, desensitization in the limbs, episodic urine and fecal incontinence. Assisted walking at short distances. At the age of 17, was assaulted and suffered the following concomitant injuries: closed craniocerebral injury; brain contusion. Cerebrospinal injury at the cervicothoracic transition level. Multiple stab wounds to the neck, chest and abdomen; pneumothorax on the left; ruptured spleen. Immediately after receiving the injuries, there were no movements in arms and legs, sensibility, self-maintained urination and defecation. Due to the long-term rehabilitation, significant progress was observed, the patient started to walk considerable distances, and bowel and bladder functions were partially restored. Approximately 1.5 year prior to admission, the patient observed a slow worsening of neurological symptoms, movement difficulty in the limbs and aggravation of numbness. Conservative therapy and rehabilitation therapy turned out to be inefficient, for which reason the patient was seen by a neurosurgeon, and surgical treatment was offered.

Diagnosis: Posttraumatic cystic adhesive arachnoiditis at C7-Th1 level. Myelopathy at C7-Th1 level.

Neurological status includes spastic tetraparesis scored up to three in lower limbs, up to four in upper limbs; surface desensitization from Th2 level, severe disturbance of deep sensibility in legs, and impairment of bowel and bladder functions akin to neurogenic bladder. MRI revealed myelopathy focus at C7-Th1 level, cystic adhesive process at this level, and impairment of CSF flow (in MR-myelography) (Figure 18).

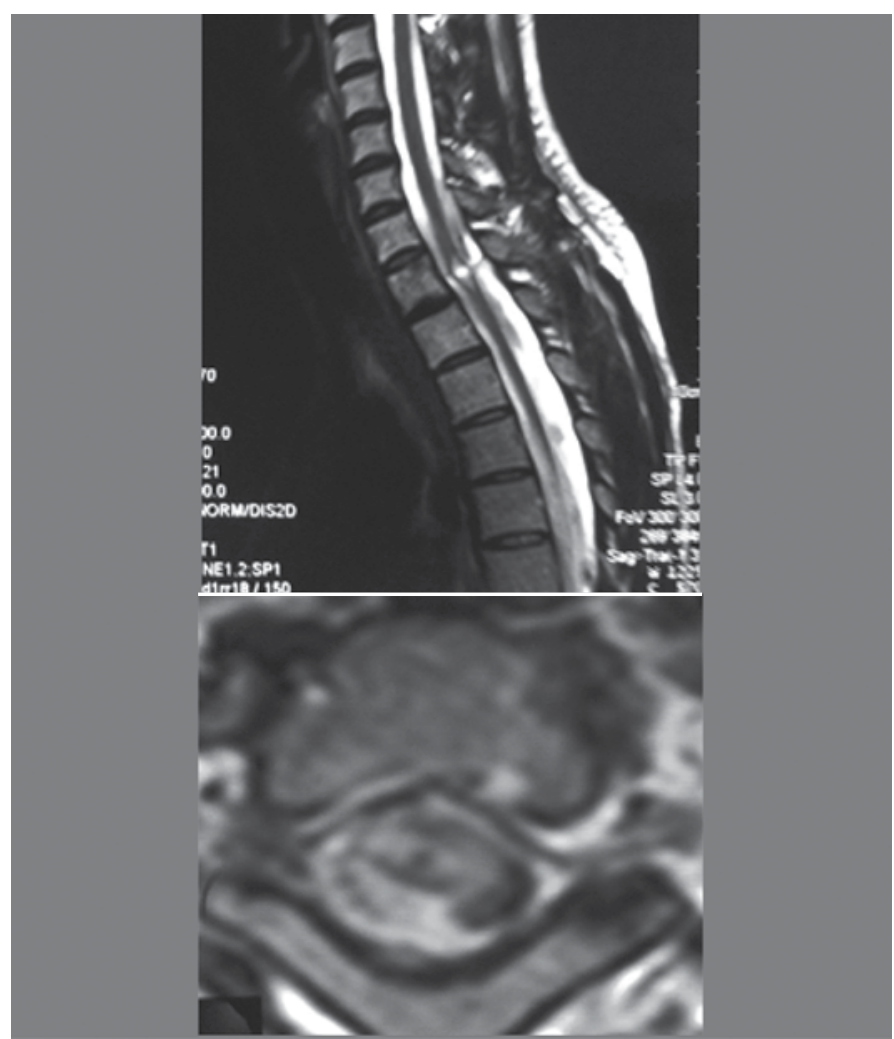

Figure 18. Posttraumatic cystic adhesive arachnoiditis at C7-Th1 level. Myelopathy at C7-Th1 level.

The patient received a surgical intervention: laminectomy at Th1 level, adhesiolysis, and thecaloscopic adhesiotomy. During the surgery, a marked adhesion on the spinal cord was found at C7-Th1 level, which was dissected. In the thecaloscopy in caudal direction from the site of operative approach (Th4-Th5 level), marked ventral and dorsal adhesions were detected, also fixing the spinal cord and building up the walls of the arachnoid cysts. These were endoscopically dissected; restoration of spinal pulsation and normalization of CSF passage were then observed.

The patient was encouraged to walk on the day following the intervention. Regression of neurological symptoms manifested as a decrease in spasticity (by one point on the Ashworth scale), absence of pelvic disturbances, and improvement of surface and deep sensibility were observed. The wound healed by primary intention, and the patient was discharged on 6th day after the surgery. The 6-month follow-up showed that the improvement in neurological status was stable, and there was no evidence of relapse of the adhesions. The patient walks unassisted and has returned to her studies at university.

\section{DISCUSSION}

The worsening of symptoms that occurred 11 years after the injury was likely to be related to decompensation of spinal cord blood flow against the progressive adhesive process at the site of traumatic injury, accompanied by compression of the spinal cord and impairment of CSF flow. Some authors consider autoimmune responses to be a likely mechanism of delayed adhesive process development in such patients, similarly to the delayed period of severe brain injury. ${ }^{7}$ Thecaloscopy enabled us to effectively perform fenestration of the adhesions and decompression of the spinal cord, including in the caudal direction from the site of operative approach, where adhesions had not been precisely verified in the preoperative MRI. Thecaloscopy enabled a stable regression of neurological symptoms to be achieved, with considerable improvement in the patient's quality of life, and contributed to her early medical and social rehabilitation. 


\section{CONCLUSIONS}

We have applied the thecaloscopy method in home neurosurgery for the first time. In our opinion, thecaloscopy is an efficient and safe method that should be widely used for surgical treatment of adhesive spinal arachnoiditis and arachnoid cysts. Our preliminary results show that this method has an advantage over open microsurgical intervention, providing better clinical outcome, shorter hospitalization times, lower level of surgical invasion, and faster patient recovery.
Thecaloscopy also enables the surgeon to perform a biopsy of an extramedullary mass, with video-assistance in spinal cord fixation syndrome. Further investigations will help us to expand thecaloscopy indications and assess delayed effects of surgical treatment.

All authors declare no potential conflict of interest related to this article.

CONTRIBUTION OF THE AUTHORS: Each author made significant individual contributions to this manuscript. AG and AK were the main contributors in the drafting of the manuscript. AG, SA and AK performed the surgery, followed up patients and gathered clinical data. SA and AK evaluated the data of the statistical analysis. SA and AK performed the literature search and review of the manuscript, and contributed to the intellectual concept of the study.

\section{REFERENCES}

1. Warnke JP, Tschabitscher M, Nobles A. Thecaloscopy: the endoscopy of the lumbar subarachnoid space, part I: historical review and own cadaver studies. Minim Invasive Neurosurg. 2001;44(2):61-4.

2. Alvisi $C$, Cerisoli M, Giulioni M, Guerra L. Long-term results of surgically treated congenital intradural spinal arachnoid cysts. J Neurosurg. 1987;67(3):333-5.

3. Gusev El, Grechko VE, Burd GS. Nervous disorders. Moscow: Medicina; 1988.

4. Di leva A, Barolat G, Tschabitscher M, Rognone E, Aimar E, Gaetani P, et al. Lumbar arachnoiditis and thecaloscopy: brief review and proposed treatment algorithm. Cent Eur
Neurosurg. 2010;71(4):207-12

5. Kumar K, Malik S, Schulte PA. Symptomatic spinal arachnoid cysts: report of two cases with review of the literature. Spine (Phila Pa 1976). 2003;28(2):E25-9.

6. Shimoji K, Ogura M, Gamou S, Yunokawa S, Sakamoto H, Fukuda S, et al. new approach for observing cerebral cisterns and ventricles via a percutaneous lumbosacral route by using fine, flexible fiberscopes. J Neurosurg. 2009;110(2):376-81.

7. Warnke JP, Mourgela S. Endoscopic treatment of lumbar arachnoiditis. Minim Invasive Neurosurg. 2007;50(1):1-6 